\title{
State and Stateless Nationalisms, Old and New Diversities, and Federal Governance
}

\author{
By Luis Moreno
}

As governments deal with the various manifestations of ethnicity and nationalism, federalism has been considered a powerful strategy to accommodate diversity and to manage conflict in contemporary societies. This chapter deals with the institutionalization of the federal idea concerning nationalism in both its state and stateless --or majority and minority-- expressions. The interrelationship between federalism and nationalism in plural-multicultural polities is multifaceted. While federalism aims at the institutional conciliation of unity and diversity (Marc and Aron1948, Duchacek 1970, Elazar 1974), nationalism can be conceptualized as politicized ethnicity (Gellner 1983, Smith 1986, Connor 1994).

The exercise of power in a nationalist context and the desire to differentiate one community from another can involve various types of diversities, such as language, culture, religion, or ancestry. In modern democracies, individual equality among citizens is often replaced by a concurrent parity among groups or organizations of individuals (Dahl 1971). Often it happens that ethnic or cultural bonds prevail upon those of a functional nature --class or status-- in the deployment of collective action (Moreno and Lecours 2010, 5). When diversity has a territorial underpinning, the federal idea has been claimed to provide a sound theoretical basis for dealing with diversity and multiculturalism in plural societies. In general terms, federalism can be conceptualized as the institutional articulation of territorial unity and diversity by means of political pact within compound polities.

After reviewing theoretical concepts and premises, a distinction between 'old' and 'new' diversities is carried out prior to the discussion on managing diversity in 
federal countries. Based upon previous research on twelve federal countries, ${ }^{1}$ including Australia, Belgium, Brazil, Canada, Ethiopia, Germany, India, Nigeria, Russia, Spain, Switzerland, and the United States of America, six "ideal types" of federal countries are identified around the world. The purpose of this analytical exercise is to highlight the various federal institutional strategies concerning the management of diversity, particularly in plural-multicultural societies. The last section of this chapter illustrates federal experiences by reviewing arrangements concerning ethno-national, linguistic, religious and multiculturalist diversities provided by the cases under observation. Concluding remarks point out that federal governance can be useful not just for territorially concentrated diversities --the main focus of this chapter-- but increasingly for new non-territorial diversity as well.

\section{Concepts and premises}

The aim of this section is to succinctly review concepts related to our analytical context, particularly those which interact more closely in producing various institutional responses around the world. Not all related theoretical categories --for example, corporatism, individualism or statism, to name a few-- are scrutinized. The following review seeks primarily to set the analytical boundaries of those concepts directly concerned with managing diversity heterogeneous populations in multinational societies.

As a powerful modern ideology, two main types of nationalism can be distinguished. Firstly, a state or majority nationalism forged by modernization and industrialization in the processes of state formation and nation-building. This form of nationalism has aimed at integrating either ethnically homogeneous societies, such as

\footnotetext{
${ }^{1}$ Under the sponsorship of the Forum of Federations and the International Association of Centers for Federal Studies (“A Global Dialogue on Federalism"), a group of experts and academics carried out during 2008-10 research for the preparation of the chapters included in the book edited by Moreno \& Colino (2010).
} 
Germany or Sweden, or heterogeneous ones, such as Italy or the USA. Secondly, a stateless nationalism --often labeled also as minority or peripheral-- has come to reassert their ancestral, or pre-union identities, through political mobilization for the achievement of democratic home rule (e.g. Catalonia or Scotland) (Hroch 1985, Coakley 1992, Beramendi et al. 1994, Safran and Máiz 2000).

$\underline{\text { State or majority nationalism }}$ consolidated as an ideological force of mobilization against absolutist monarchy. In modern times, the most dynamic sectors of the bourgeoisie and some elites of the peasantry also made use of this nationalist ideology in order to fight the old aristocratic privileges. The concept of citizenship drafted by the English Revolution and articulated by both US and French revolutions became essential in the conformation of state nationalism during the 19th and 20th centuries (Brubaker 1996). Its final aim was no other that the building of nations where citizens would become peers with equal access to a set of universal rights and obligations. Thus, nations forged by this type of state nationalism were to become the embodiment of modernity (Tivey 1981, Greenfeld 1992, Llobera 1994).

In modern Europe, hegemonic ethno-territorial groups $(\text { Staatvolker })^{2}$ often implemented programs of nation-building and state formation with varying results and outcomes (e.g. Castilians, English, Piedmontese or Prussians). In some instances such groups claimed to be the main or exclusive representatives of their states, an allegation which became difficult to maintain with the passing of time (e.g. Walloons in the case of Belgium).

\footnotetext{
2 These are regarded as national ethnic peoples who are demographically and electorally dominant, although they do not add up to an absolute majority of the population. Such ethnoterritorial groups have often played the role of facilitating the country's political stability by means of hierarchical and 'command-and-control' programs of state formation (Peleg 2007).
} 
Stateless or minority nationalism generally develops within plural states and is associated with demands for self-government. ${ }^{3}$ These can range from a degree of home rule to the formation of a new independent state. This type of nationalist mobilization is somewhat analogous to that of regionalism. Although they cannot be considered as synonymous, both share three elements in most of their manifestations: (a) A collective identity and consciousness of community belonging; (b) A centre-periphery, or majority-minority conflict; and (c) An existence of social mobilization and political organization for the achievement of their objectives.

State or majority nationalism has been labeled 'civic' or 'unifying' as opposed to 'ethnic' or 'secessionist' minority nationalism. The former is widely considered to be a superior manifestation of human civilization and progress. The latter, instead, is viewed as a failed spin-off of history, which is bound to provoke permanent conflicts and violence (e.g. recent collective tragedies in the ex-Yugoslavia or genocide in Rwanda). Both forms of nationalism can be pathological in various degrees and scales. In fact, state nationalism is to be associated with the worst episode in human history: the Holocaust (Moreno and Lecours 2010, 4).

The federal idea contends that diversity can be recognized by legitimate means. Where conflict arises, federalism underlines the meaning of diversity by making its institutional accommodation possible. Federalist claims are behind the working out of arrangements between territorial units in federal countries. In various modes and guises, federal provisions are not mechanisms for "disguising" internal oppositions, although they can be instrumentalized for such a purpose. Certainly, the federal experience is seen to be more fruitful in those countries with a political culture of negotiation, and

\footnotetext{
${ }^{3}$ It can also affect to two o more neighboring states, as the Basque or Kurdish cases illustrate (Conversi 2003; Moreno 2003; Natali 2005).
} 
tolerance. Furthermore, federalism has also allowed for the accommodation of nonterritorial diversity concerning, for instance, the recognition of multicultural rights.

A substantial element of the federalist philosophy is revealed in its own etymological origin. The Latin word foedus means pact or agreement. This idea of covenant providing the basis for the federal government is its fundamental characteristic (Elazar and Kincaid 2000). According to the federal principle, the abstract general should be replaced by a concrete will reflected in agreements among citizens and embodied in institutions promoting self-rule and shared rule (Elazar 1995; Watts 2001).

Consociationalism can be regarded as an alternative idea of government to the federal model. It can be observed in some European countries, such as Belgium, the Netherlands, or Switzerland. Central to consociationalism is power-sharing in government. Other elements including mutual vetoes, proportionality and segmental autonomy are --arguably-- of lesser importance. The lack of one or more of these lesser elements has provided the grounds for challenging whether a political system may be considered truly consociational or not (Guelke 2010).

Despite deep social divisions and the persistence of long-term societal cleavages (ideological, confessional and linguistic), polities can be successfully managed with consociationalist practices (Lijphart 1969). A trait of consociationalism, although not wholly generalized to all instances of this from of government, is that the sectional diversities do not necessarily have a spatial reference within the polity and may be cross-sectional as the case of the Netherlands illustrates.

Multiculturalism deals with the dilemma of how collective rights could square with individual rights in the context of plural and heterogeneous societies (Taylor 1994; Kymlicka 1995). It opposes the very idea of assimilation or the dissolution of diversity into one single and unifying loyalty to the polity. Broadly speaking, multiculturalism is 
interested in reconciling the realities of group and cultural belonging with the tenets and practices of liberalism. Therefore, normative views on the politics of recognition advocate for collective rights in multicultural societies to be fully compatible with individualistic liberalism. $^{4}$

The discussion on how to implement multicultural policies or, more generally, which minority cultures(s) should have recognition and institutional support is highly debated. Through an analysis of arguments such as the quality of a culture, its compatibility with the dominant culture, the seniority of a group within the state, and its demographic weight, William Safran has underlined the fact that not all cultures and multicultural policies affect national coherence and democratic practices in a similar way (Safran 2010). On criticizing Jacobin supporters of the French Revolution, Safran already pointed out how the conflict between the rights of the individual --viewed as a socially autonomous unit-- and the traditional rights of social groups or collectivities can be exacerbated (Safran 1987).

\section{'Old' and 'New' Diversities}

Diversity can be regarded as the condition for a polity of being composed of differing types of cultural or ethnic groups. It is one of the most contested issues in national and international politics. Debates about ethnic, national, linguistic, religious, and economic diversity and its accommodation in viable and legitimate polities feature prominently in discussions among academics and practitioners in various disciplinary fields, such as comparative politics, conflict-resolution studies, political sociology, and political theory. A classification of 'old' --or long-standing-- diversities can be summarized as follows:

\footnotetext{
${ }^{4}$ This is particularly relevant for minority nationalist movements --in stateless nations-- which aspire to political autonomy but not necessarily to "sovereign" independence (Moreno 1999; Keating 2001; Loughlin 2001).
} 
(a) Those pertaining to cultural, ideological, linguistic, racial, and religious predispositions. When these are concentrated territorially, they may be more difficult to manage institutionally, and they are the ones for which federal arrangements claim to be most adequate.

(b) Those concerned with group identities explicitly manifested by the collectives involved - and which can be based upon diversities referred to in type (a) above. The existence of politically mobilized territorial or national self-defined identities in multiethnic or multinational societies represents a paramount challenge for the governance and accommodation of differences.

(c) Those concerning socio-economic resources and the interests of groups concentrated territorially. Socioeconomic differences revolve around the allocation of socially valued goods and the redistribution of resources among territories, and are sometimes a common rationale of federal arrangements.

Concerning (a), language is crucial not only in the building and self-definition of different communities, but also in the creation of a common sphere of public discourse (Braen et al., 2006; Williams, 2007). Religion is also crucial in making and shaping diverse groups and heterogeneous polities. Not surprisingly, the protection of linguistic and religious minorities has been an original terrain for expansions of minority rights. As regards (b), both national minorities and indigenous populations in settler societies have increasingly demanded self-government rights and the establishment of separate institutions in their homeland territories where they often constitute the majority. They have also sought the creation and protection of reserved lands. In both cases, groups linked to this so-called 'deep diversity' aspire to full jurisdiction over powers relevant to their cultural survival and nation-building. With relation to (c), it is to be underlined that in many countries such diversities overlap with other non-territorial differences related 
to class, economics or gender, which can be more or less politicized (Moreno and Colino 2010, 4).

The extension of 'new' diversities as a result of international migrations has increased in recent times. Thus, new minorities struggle to gain recognition of their cultural differences and seek inclusion in common institutions (Koenig and de Guchteneire 2007). This phenomenon has further consequences in federal countries, where immigration not only relates to the countries involved, but also affects the cultural composition of the various constituent units. These may feel threatened by new minorities, which may cause tensions between the demands of minority nations and the cultural rights of ethnic migrants. In those federations with distinct national identities in several constituent units, such as Catalonia and Quebec, the integration of immigrants with different languages and cultures is regarded as a further strain on the political aspirations or nation-building projects advocated by stateless or minority nationalism.

Figures concerning demographic changes are very telling. In Canada, for instance, there are more than 6 million foreign-born people, accounting for virtually 20 percent of the population. In some metropolitan areas such as Toronto and Vancouver, the proportions of foreign-born residents are 45.7 and 39.6 percent respectively. In the United States, a country historically formed by several waves of foreign immigration, 12.6 percent of the population (38.1 million people) is foreign-born. In long-standing federations, such as Switzerland, the number of foreigners increased from 120,000 in 1950 (6 percent of Switzerland's population) to 1.7 million (22.1 percent) in 2007. Germany's foreign-resident population amounts to 6.7 million, which is 8.2 percent of the total population, with an unequal distribution of immigrants throughout the Länder. The immigrant population doubled from 2,664,168 in 2003 (6.2 percent of the total population) to 4,482,568 in 2007 (10 percent) (Moreno and Colino 2010, 389-0). 
In their management of diversity, federal countries have to deal with a "recognition agenda" (e.g., accepting cultural differences, building accommodation, or facilitating minorities' aspirations) and with an "integration agenda" (e.g., allowing minorities' views into mainstream politics, reinforcing societal bonds, or strengthening mutual support and solidarity) (Banting et al. 2007; Fossum et al. 2009). ${ }^{5}$

It is important to point out that diversity may or may not gain political expression and therefore does not necessarily imply conflict (Poirier 2008). Institutional crystallizations of the federal idea range from: (a) practically homogenous polities (e.g., Germany), to (b) ethnically heterogeneous ones with no territorial ascription or concentration of ethnic groups (e.g., Brazil and the United States), and (c) to polities with multiple ethno-territorial diversity (e.g., India, Nigeria, and Switzerland). Different combinations or configurations of ethnic or non-ethnic diversities are a relevant factor in many federations and federal-like systems.

At current, there are around sixty-five countries where there is at least one territorially concentrated minority that either accounts for more than 5 percent of the population or amounts to half a million people. Only fifteen of those countries are organized with federal arrangements; thus, most diverse countries are not federations. There are nine federal systems where minorities are non-territorially concentrated (e.g., Argentina, Austria, and Germany) and others that have significant minorities, indigenous or other, but mostly without an identifiable territory of their own, and which were not designed to empower such minorities politically (e.g., Australia and the United States) (Wibbels and Babke 2006). ${ }^{6}$

\footnotetext{
${ }^{5}$ In compound polities, the various types of diversity overlap and/or are interconnected, making the picture still more complex (Cf. Linz, 1997; Agranoff, 1999; Gagnon et al., 2003; Gagnon and Tully, 2001; Choudhry, 2008; McEwen and Lecours, 2008; Watts and Chattopadhyay, 2008).

${ }^{6}$ Studies on ethnic diversity and how to measure it often offer useful indices and measurements, although they do not focus exclusively on federations or federal systems. See Gurr et al., 1993 and Alesina et al. 2003.
} 
Among those fifteen federal states with politically relevant ethnic minorities, different institutional responses to ethnic diversity can be found. In some cases, the federal structure ignores ethnic issues or responds to concerns having nothing to do with empowering such groups. The boundaries of constituent units cut across ethnic groups (e.g., the United States and Brazil). In other cases, the federal structure reflects ethnic diversity somewhat, but the configuration of constituent units' boundaries divides at least the largest ethnocultural group and sometimes other groups as well (e.g., Switzerland, Canada, Spain, Russia, and Nigeria), and certain ethnolinguistic groups enjoy autonomy under the federal system, but are divided among several constituent units. In a small number of cases, the federal structure reflects the territorial distribution of the ethnic groups (e.g., Belgium and Ethiopia) (Moreno \& Colino 2010, 395).

\section{Managing Diversity in Federal Countries}

Federal institutions and ideas have often been put into practice for the accommodation of ethno-linguistic or religious diversities, to empower ethnic or linguistic minorities, or to manage conflicts. In most of the countries, the aim has been to establish a legitimate, stable and cohesive order (Majeed et al. 2008, Erk and Anderson 2009, McGarry et al. 2008).

Several dimensions have been pointed out as being important: (a) the extent to which there is a single dominant cultural or ethnic group and a variety of minorities in the country; (b) the extent to which those minorities have a long established presence within that society or are formed by new migrants producing a new politics of difference; or (c) the extent to which their political identities are strong and politically mobilized or are assimilated into the majority cultural group. Also crucial is the extent 
to which different ethno-linguistic or cultural groups are either concentrated within a particular geographic area or dispersed throughout the society. ${ }^{7}$

Federal strategies for managing diversity that emphasize integration and inclusion of ethno-cultural differences and those that emphasize the autonomy and empowerment of those groups or territories can be distinguished (Choudry 2008). Other strategies seek to maintain some common bonds and unity because too much emphasis on diversity may neglect the common bonds that unite communities and individuals. Different strategies are more likely to work more effectively in some contexts than in others. The institutional strategies applied may account for different degrees of stability, social justice, legitimacy, equity, recognition, social integration, and accountability achieved by the federal system.

Which federal arrangements are adequate to deal simultaneously with both old diversities (e.g., national-ethnic identities and demographic or economic divergence) and new diversities (e.g., aboriginal peoples' recent demands based on ancestral claims, as well as 'new' immigration)? Do they provide with institutional appropriate means for managing these diversities? Such questions cannot be answered with universal and 'fitfor-all' prescriptions, as the twelve cases examined clearly indicate. However, and for the purpose of contrasting institutional arrangements to the management of diversity, six “ideal types” can be identified (Moreno and Colino 2010, 380):

(1) National federations that are mostly monolingual and have historical and newly created political units with new groups of immigrants unequally distributed across the constituent units. Political parties are predominantly federation-wide, and

\footnotetext{
${ }^{7}$ On various institutional arrangements and its likely consequences, cf. Suberu (2001), Brancati (2006), Kymlicka, (2006), Norman (2006), Bajpai (2007), and Stepan (2007, 2008).
} 
institutional arrangements and resources are fairly centralized or shared concurrently (e.g., Germany).

(2) National federations with small indigenous populations, old immigrant or settler groups, different religions, a dominant lingua franca, and predominantly federation-wide parties. New diversities are not concentrated territorially, and the federal government retains a significant political role (e.g., Australia, Brazil, and the United States).

(3) Multilingual, multi-unit, recently established federal countries, with a dominant lingua franca and a dominant national identity but with several mobilized minority national groups and increasing new religious and cultural diversity. There are strong federation-wide parties but also strong regional parties in some constituent units, and there are certain elements of asymmetry and considerable decentralization in institutional arrangements (e.g., Spain).

(4) Multilingual and multicultural federations (largely bi- or tri-communal) with no national lingua franca, but which have strong local identities compatible with a federation-wide identity. There are weak --or non-existent-- federation-wide parties, and there is increasing new polyethnic diversity within the constituent units because of new immigration, and the distribution of competences is very decentralized (e.g., Belgium and Switzerland).

(5) Bilingual federations where several national groups are mobilized, with one of them being dominant, and where indigenous populations are mobilized too. Nonfederation-wide parties are strong, and there is an increasing polyethnicity due to new immigration with institutional arrangements showing much decentralized powers and resources (e.g., Canada). 
(6) Multiethnic, multilingual, and multi-religious federal countries with multiple constituent units, which are designed mainly along ethnic or linguistic lines. There may be one lingua franca or major ethnic group in several units. There are different configurations of party systems, strong socioeconomic disparities, and large internal migration flows (e.g., Ethiopia, India, Nigeria, and Russia).

In the twelve cases considered, two main approaches can be distinguished concerning institutional responses to tackle specific types of diversity as follows:

(1) Integration and inclusion of ethno-cultural differences and its privatization is sought by means of securing individual rights and promoting citizens' equality before the law. Institutional recognition of group identities is institutionally rejected, although they accept and respect cultural or other diversity in private realms (e.g., the United States, Germany, Brazil, and Nigeria). The prototypical example is the United States, where there is a civic conception of the national community. Minority rights ought to be protected irrespective of the territory where citizens reside, and equality and nondiscrimination among individuals and territories are recognized by both the federal and state constitutions. In the case of Nigeria, the constitution does not include any specific provisions for minority rights but it guarantees the fundamental rights of "every person" to life, dignity of the human person, personal liberty, fair hearing, private life, freedom of expression and conscience, and peaceful assembly and association.

(2) Institutional arrangements and values try to publicly recognize differences and empower specific groups with collective rights. The boundaries of the constituent units may reflect those group differences or identities. The representation of groups and minorities as such, not as individuals, is institutionally recognized (e.g., Ethiopia and Belgium). As often happens, there is a constitutional distinction between "nationalitybased units" and federated constituent units that are considered as subdivisions of a 
larger national majority. The constitution --and/or subsequent legal and political developments-- seeks to "channel" the country's fundamental diversities through the constituent units.

Whether formal or informal, there is a combination in some cases of these two approaches. While there may be some elements of recognition to specific groups territorially concentrated --like indigenous or aboriginal groups which are granted special collective rights, or internal self-defined nations-- most diversities are regarded to affect to the individuals and are protected through individual rights (e.g., India, Canada, Spain, and Russia). An important consideration in this respect is that despite the recognition of nationality or ethnically based constituent units, some population overlaps and institutional arrangements are unavoidable so that minorities within minorities can be protected.

\section{Ethno-National, Linguistic, Religious, Multiculturalist Diversities, and Federal}

\section{Experiences}

The twelve countries under observation provide plenty of instances by which federal governance can accommodate diversity. The succinct analysis of some ethnonational, linguistic, religious and multiculturalist diversities seeks to illustrate the degree and scope of federalist experiences around the world (Moreno and Colino 2010, $\left.383-9^{8}\right)$. A comprehensive list of issues and questions is not possible to enumerate. However, the review of some constitutional and political arrangements may validate the claim that federalism can conciliate state and stateless nationalisms aspirations and facilitate diversity in unity in plural societies. The purpose of this section is not to apply evaluative criteria by which degrees of "success" or "failure" in integrating diversity could be ranged in the various federal countries examined. Rather, it identifies different

\footnotetext{
${ }^{8}$ Primary evidence supporting the analyses in this section have been provided by authors of the chapters included in this book.
} 
institutional arrangements in the twelve case studies analyzed for the purpose of highlighting variations. It also seeks to group federal experiences according to the three main domains considered to be crucial in the production and reproduction of diversity around the world, in order to provide comparisons for a better understanding of possible future developments.

\section{Ethnicity and Nationality}

Ethnic cleavages are disregarded in some federations and territorial boundaries of the constituent units cut across ethnic groups (e.g., Brazil, Nigeria, Switzerland, and the United States). Others recognize the constitutional possibility and flexibility for redesigning the internal boundaries along ethnic or ethnolinguistic lines, or adding units to the federation which, sometimes, are carved out of existing units (e.g., Ethiopia and India). In federations such as the United States, there is no practical constitutional means to re-design state or local boundaries to encompass cultural groups.

The territorial distribution of ethnic groups is made visible in other federations (e.g., Belgium, India, and Ethiopia). In some instances, the boundaries of the constituent units reflect the country's territorial ethno-linguistic diversity, although the largest ethnocultural group is also distributed across many of those units (e.g., Canada, Nigeria, Russia, and Switzerland). The Russian Constitution mentions minorities, but refrains from defining them. Awarding different constitutional status to the various types of constituent units is also an option for managing diversity (e.g., Russia). The principle of "federal character" in Nigeria, meaning the aspiration of equitable representation of constituent state "indigenes" in the country's central political institutions, is another example of accommodation. "Indigenes" are defined not residentially but by descent from parents or grandparents belonging to a community indigenous to a state. 
Leaving ambivalent the constitutional definition of the constituent communities, or the scope of the federal arrangements, may allow state and stateless nationalisms to interpret the very nature of the federal governance differently. This may avoid the "swallowing" of a particular definition of diversity or national membership favored by majoritarian or state-wide groups (e.g., Canada and Spain). On the other hand, the right of secession can be constitutionally recognized in order to "forestall" forced territorial assimilation of the constituent units. Ethiopia's Constitution expressly incorporates the right of nationalities to secede after complying with some procedures. In contrast, no right of secession is recognized in most of the other traditional federations. In Switzerland despite that the Constitution allows for the redrawing of internal boundaries, unilateral right to secede is not granted. In Canada, the Supreme Court established in 1998 that unilateral secession was constitutionally invalid, but in the circumstances where a clear will of the population concerned had been expressed after popular consultation the federal government would be obliged to negotiate secession.

\section{Language and Religion}

Promotion of a lingua franca is a common feature in several federal countries (e.g., Amharic in Ethiopia, Castilian-Spanish in Spain, English and Hindi in India, English in Nigeria, or Russian in the Russian Federation). In parallel, there is frequently the constitutional recognition of the local languages, and the right for citizens to use their vernacular languages. Switzerland has preferred official unilingualism in most of the cantons. Canada has advocated bilingualism at the federal level and different arrangements according to the provinces.

Language arrangements apply to individuals and disregard citizens' place of residence as regards cultural communities in Belgium and provisions of "nationalcultural autonomy" for some groups in Russia. A case in point is also the official federal 
bilingualism statutory program in Canada for dealing with French speakers anywhere within the federation. In the USA, the Constitution is silent about language, and the Congress has never proposed an amendment to establish an official language. However, amid a wave of nationalism and English-only sentiment, thirty states have in recent decades declared English their official language, and some US citizens regard English as a necessary and, even, exclusive ingredient of 'American identity'.

There is also a considerable variety of institutional responses concerning religion, ranging from the secularist exclusion of all religious matters from the public sphere to corporatist forms of religious inclusion in the federal or constituent units' institutions. In some cases, some constituent units may recognize religious law (such as Sharia in Nigeria). The latter is not the case of the USA where there are no religious tribunals although informally courts may respect decisions of religious institutions to which citizens submit voluntarily. Likewise, there are no affirmative action policies for religious groups. No religious activities, personnel, or buildings are financed by governments. In the case of Germany, there is substantial majority of those citizens registered with Christian churches (half of them Protestants and half Catholics). Germany is one of the few countries in the world where the central state collects a tax for and on behalf of the Christian churches. Religion has become a social cleavage considering the considerable high number of Muslim immigrants (4\% of the total German population, or around 3,3 million).

\section{$\underline{\text { Multiculturalism and Immigration }}$}

Multiculturalist policies to deal with new diversity have in recent times been implemented by both federal and federated governments. In some cases, as in Switzerland, the three layers of government (federal, cantonal and municipal) are actively involved in granting formally or symbolically citizenship status to immigrants. 
Such policies of integration or incorporation often aim at guaranteeing that individual inclusion and group recognition of cultural differences can be achieved simultaneously. Such policies go beyond mere non-discrimination and seek to (a) extend anti-racism policies; (b) reform education curricula to incorporate the inputs and contributions of immigrant groups; and (c) fund publicly the cultural practices of immigrant groups.

In Germany, multiculturalism is mainly non-territorial. The implementation of “integration courses" for immigrants (600 hours of German as a foreign language, and 30 hours introduction to German civilization and culture) mostly rely on cooperation between the federation and the Länder based upon the idea of Bundestreue, or principle of mutual trust, between the various orders of government in the German Bund. In Canada, the Multiculturalism Act of 1988 defines multiculturalism as fundamental to Canadian identity. Multiculturalist policies have aimed at forging a Canadian identity based on a multiplicity of cultures. In the USA territorially based multiculturalism has been excluded or eliminated from the federal system. Multiculturalist programs are rooted in the liberal idea of individual rights, as articulated by the policies of positive discrimination (affirmative action) for groups such as African Americans, women, persons with disabilities, and, to some extent, Hispanics.

Regional or federated meso-governments may require migrants to learn their local regional language, even if a common (and world) language exists in the federation. Quebec or Catalonia, for example, have been active in using their self-government powers to secure the incorporation and integration of immigrants by means of implementing their own education, labor, and language policies that support nationbuilding aspirations put forward by stateless nationalism or autonomist movements. In Russia, a shift from the stress on multiculturalism in the early Yeltsin years to statism 
under Putin is noticeable, with a revaluation of the Russian ethnos as the state-forming group and an intensifying suspicion towards Muslims.

\section{Conclusion: Assessed Utility of Federal Strategies}

Federal governance, in its different manifestations of institutional autonomy, participation in federal decisions and recognition and protection of minorities, can be useful not just for territorially concentrated diversities but increasingly for new nonterritorial diversity. Yet, there will be some federations where the conflict between historically recognized cultural communities and the individual rights of immigrants, women, gays, and so on is bound to be more acute. Indeed, federal governance cannot be regarded as a panacea to reconcile unity and diversity. The tenets of the "good society" are not alien to friction and, in some cases, conflicts. However, in its different guises federalism has proved to be relatively successful in making workable the conciliation of unity and diversity by means of political negotiation and eventually pacts. Furthermore, it has prevented a recurrence of the type of large-scale disruption that ravaged some federations under observation (e.g., Nigeria's Civil War during 196770, Ethiopia, or post-partition India).

Globalization and the parallel revival of a variety of territorial identities have coincided with an increasing challenge to the centralist model of the unitary state. In plural polities, decentralization, federalization, and subsidiarity have sought to accommodate a response to the stimuli of the diversity or plurality of the polities involved. The latter, as shown in the twelve cases considered in this chapter, comprise groups and countries with differences of identity, history, language, or traditions, which are often reflected in different party systems, channels of elite representation, and modes of interest articulation. In most of these cases the political quest remains 
concerning how to reconcile both state (majority) and stateless (minority) nationalism while dealing with diversities, old and new.*

\section{References}

Agranoff, Robert. ed. 1999. Accommodating Diversity: Asymmetry in Federal States. Nomos: Baden Baden. Nomos.

Alesina, Alberto Alesina, Devleeschauwer Arnaud, Sergio Kurlan Easterly, and Warcziarg Romain. 2003. "Fractionalization." Journal of Economic Growth 8: pp. 155-194.

Bajpai, Shankar K. ed. 2007. Democracy and Diversity: India and the American Experience. India: Oxford University Press.

Banting, Keith, Thomas J. Courchene, and F. Leslie Seidle, eds. 2007. Belonging? Diversity, Recognition and Shared Citizenship in Canada. Montréal: IRPP.

Beramendi, Justo G., Ramón Máiz, R. and Xosé-Manoel Núñez. eds.. 1994. Nationalism in Europe. Past and Present (2 Vols.). Santiago de Compostela: Universidade de Santiago de Compostela.

Braen, André; Pierre Foucher, and Ives Le Bouthillier. eds. 2007. Langues, constitutionnalisme et minorités. Markham, ON: LexisNexis Butterworths.

Brancati, Dawn. 2006. "Decentralization: Fueling the Fire or Dampening the Flames of Ethnic Conflict and Secessionism," International Organization 60 (July 2006): $651-685$.

Brubaker, Rogers. 1996. Nationalism Reframed: Nationhood and the National Question in the New Europe. Cambridge: Cambridge University Press.

\footnotetext{
* The author gratefully acknowledges the support provided by the Spanish Ministry of Education (PR2010-0095) at the time of writing this chapter.
} 
Choudhry, Sujit. ed.. 2008. Constitutional Design for Divided Societies: Integration or Accommodation? New York: Oxford University Press.

Coakley, John. 1992. “Conclusion: Nationalist Movements and Society in Contemporary Western Europe.”. In The Social Origins of Nationalist Movements, ed. John Coakley, pp. 212-230. London: Sage/Ecpr.

Connor, Walker. 1994. Ethnonationalism. The Quest for Understanding. Princeton, NJ: Princeton University Press.

Conversi, Daniele. 1997. The Basques, the Catalans and Spain. Alternative Routes to Nationalist Mobilisation. London: Hurst.

Dahl, Robert A. 1971. Polyarchy, Participation and Opposition. New Haven, CT: Yale University Press.

Duchacek, Ivo D. 1970. Comparative Federalism: The Territorial Dimension of Politics. New York: Holt, Rinehart \& Winston.

Elazar, Daniel J. ed. 1974. The Federal Polity. Philadelphia, PA: Temple University (Center for the Study of Federalism).

Elazar, Daniel J. 1995. "From Statism To Federalism: A Paradigm Shift.” Publius. The Journal of Federalism, 25 (2): 5-18.

Elazar, Daniel J. and John Kincaid. eds. 2000. The Covenant Connection: From Federal Theology to Modern Federalism. Lanham, MD: Lexington Books.

Erk, Jan and Lawrence Anderson, “The Paradox of Federalism: Does Self-Rule Accommodate or Exacerbate Ethnic Divisions?” Regional and Federal Studies, 19 (2): 191-202.

Fossum, John E.; Johanne Poirier, and Paul Magnette. eds. 2009. The Ties that Bind: Accommodating Diversity in Canada and the European Union. Bruxelles: Peter Lang. 
Gagnon, Alain-G., Montserrat Guibernau, and François Rocher. eds. 2003. The Conditions of Diversity in Multinational Democracies. Montreal: IRPP.

Gagnon, Alain-G. and James Tully. 2001. Multinational Democracies. Cambridge: Cambridge University Press.

Gellner, E. 1983. Nations and Nationalism. Ithaca, N.Y.: Cornell University Press.

Greenfeld, Liah. 1992. Nationalism. Five Roads to Modernity. Cambridge, Mass.: Harvard University Press.

Guelke, Adrian. 2010. “A consociational democray or Anglo-Irish conflict management? The St Andrews Agreement and the political accommodation of Irish nationalism.” In Nationalism and Democracy. Dichotomies, Complementarities, Oppositions, ed. André Lecours and Luis Moreno, pp. 247261. New York: Routledge.

Guibernau, Montserrat. 1996. Nationalisms. The Nation-State and Nationalism in the Twentieth Century. Cambridge: Polity Press.

Gurr, Ted R., with Barbara Harff, Monty G. Marshall, and James R. Scarritt. 1993. Minorities at Risk: A Global View of Ethnopolitical Conflicts. Washington, DC: U.S. Institute of Peace.

Hroch, Miroslav. 1985. Social Preconditions and National Revival in Europe. A Comparative Analysis of the Social Composition of Patriotic Groups among the Smaller European Nations. Cambridge: Cambridge University Press.

Keating, Michael. 2001. Plurinational Democracy. Stateless Nations in a Postsovereign Era. Oxford: Oxford University Press.

Kymlicka, Will. 1995. Multicultural Citizenship: A Liberal Theory of Minority Rights. Oxford: Clarendon Press. 
Kymlicka, Will. 2006. "Emerging Models of Multination Federalism: Are they Relevant for Africa?" In EthnicFederalism: The Ethiopian Experience in Comparative Perspective, ed. David Turton, pp. 32-64. Oxford: James Currey.

Koenig, Matthias and Paul de Guchteneire. 2007. "Political Governance of Cultural Diversity." In Democracy and Human Rights in Multicultural Societies, eds. Matthias Koenig and Paul de Guchteneire, pp. 3-14. Aldershot: Ashgate/UNESCO.

Lijphart, Arend. 1969. “Consociational democracy.” World Politics, 21 (2): 207-225. Linz, Juan J. 1997. "Democracy, multinationalism and federalism.” Working Paper 1997/103, Madrid: CEACS-Fundación Juan March.

Loughlin, John. ed. 2001. Subnational Democracy in the European Union: Challenges and Opportunities. Oxford: Oxford University Press.

McGarry, John; Brendan O'Leary and Richard Simeon. 2008 "Integration or Accommodation: The Enduring Debate in Conflict Regulation.” In Constitutional Design for Divided Societies: Integration or Accommodation?, ed. Sujit Choudhry, pp. 41-90. Oxford University Press.

Majeed, Akhtar ; Jonahis A. Elaigwu, Thomas Fleiner and Mahendra P. Singh. 2008. "Building on and Accommodating Diversities." In Building on and Accommodating Diversities, Unity in Diversity. Learning from Each Other (Vol. 1), pp. 3-20. New Delhi: Viva Books.

Marc, Aleixandre and Raymond Aron. 1948. Principles du Federalism. Paros: Le Portulan.

Moreno, Luis. 1999. "Local and Global: Mesogovernments and Territorial identities." Nationalism and Ethnic Politics, 5 (3/4): 61-75. 
Moreno, Luis. 2003. "Divided societies, electoral polarization and the Basque Country." In Democracy and Ethnic Conflict, ed. Adrian Guelke, pp. 29-51.

Basingstoke/New York: Palgrave Macmillan.

Moreno, Luis and César Colino. 2010. "Introduction: Diversity and Unity in Federal Countries.”, In Diversity and Unity in Federal Systems, ed. Luis Moreno and César Colino, pp. 3-15. Montreal \& Kingston/London/Ithaca: McGill-Queen's University Press

Moreno, Luis and Lecours, André. 2010. "Introduction: tensions and paradoxes of a multifaceted relationship". Nationalism and Democracy. Dichotomies, complementarities, oppositions, ed. André Lecours and Luis Moreno, pp. 3-15. London/New York: Routledge.

Natali, Denise. 2005. The Kurds and the State: Evolving National Identity in Iraq, Turkey, and Iran. Syracuse, NY: Syracuse University Press.

Nairn, Tom. 1997. Faces of Nationalism. Janus Revisited. London: Verso.

Wayne Norman, Wayne. 2006. Negotiating Nationalism: Nation- Building, Federalism, and Secession in the Multinational State. New York: Oxford University Press.

Peleg, Ilan. 2007. Democratizing the Hegemonic State. Political Transformation in the Age of Identity. Cambridge: Cambridge University Press.

Poirier, Johanne Poirier. 2008. “Autonomy and Diversity.” In Building on and Accommodating Diversities, ed. Ronald L. Watts and Rupak Chattopadhyay, pp. 37-53. New Delhi: Viva Books.

Safran, William. 1987. "Ethnic Mobilization, Modernization, and Ideology: Jacobinism, Marxism, Organicism and Functionalism.” The Journal of Ethnic Studies 15 (1): 131. 
Safran, William. 2010. "Multiculturalism, ethnicity, and the nation-state. Ideology, identity, and policy." In Nationalism and Democracy. Dichotomies, complementarities, oppositions, ed. André Lecours and Luis Moreno, pp. 16-37.

Safran, William and Ramón Máiz. eds. 2000. Identity and territorial autonomy in plural societies. London: Frank Cass/Routledge.

Smith, Anthony D. 1986. The Ethnic Origins of Nations. Oxford: Basil Blackwell.

Stepan, Alfred. 2007. "Federalism, Multi-National Societies, and Negotiating a Democratic 'State Nation': A Theoretical Framework, the Indian Model and a Tamil Case Study." In Democracy and Diversity: India and the American Experience, ed. Shankar K Bajpai, pp. 225-261. India: Oxford University Press. Stepan, Alfred. 2008. "Comparative Theory and Political Practice: Do we need a 'State-Nation' Model as well as a 'Nation-State' Model?,' Government and Opposition 43: 1-25.

Suberu, Rotimi T. 2001. Federalism and Ethnic Conflict in Nigeria. Washington, DC: U.S. Institute of Peace Press.

Taylor, Charles. 1994. Multiculturalism. Examining the Politics of Recognition. Princeton, NJ: Princeton University Press.

Tivey, Leonard. ed. 1981 The Nation-State. The Formation of Modern Politics, Oxford, Martin Robertson.

Watts, Ronald L. 2001. "Models of federal power-sharing.” International Social Science Journal, 167: 23-32.

Watts, Ronald L. and Rupak Chattopadhyay. eds. 2008. Building on and Accommodating Diversities. New Delhi: Viva Books.

Wibbels, Erik M. and Kristin Bakke. 2006. "Diversity, Disparity, and Civil Conflict in Federal States.” World Politics 59: 1-50. 
Williams, Colin H. ed. 2007. Language and Governance. Cardiff: University of Wales Press. 